\title{
Sexual reproduction in the newly-described blue diatom, Haslea karadagensis
}

\author{
Nickolai A. Davidovich ${ }^{1 *}$, Romain Gastineau ${ }^{2}$, Pierre Gaudin ${ }^{3}$, Olga I. Davidovich \\ ${ }^{1} \&$ Jean-Luc MougeT ${ }^{2}$
}

\author{
${ }^{1}$ Karadag Natural Reserve of the National Academy of Sciences, p/o Kurortnoe, Feodosiya, Ukraine, 98188; \\ *Corresponding authore-mail: nickolaid@yandex.ru; fax: +0380656226212 \\ ${ }^{2}$ EA 2160, MMS-Mer, Molécules, Santé, Université du Maine, Avenue Olivier Messiaen, 72085 Le Mans CEDEX \\ 9, France \\ ${ }^{3}$ EA 2160, MMS-Mer, Molécules, Santé, Université de Nantes, 2 rue de la Houssinière, 44322 Nantes CEDEX, \\ France
}

\begin{abstract}
For decades, the diatom genus Haslea has been known to comprise both "colorless" species and one species containing a blue pigment, the latter being known as $H$. ostrearia. Recently, a new blue diatom named $H$. karadagensis has been isolated from the Black Sea. The mating compatibility of the two species has been tested, and their reproductive isolation confirmed. We provide a detailed description of the heterothallic sexual reproduction process in this new species. Cells from clones which are sexually compatible arrange gametangial pairs. Each gametangium in the pair produces two gametes, which to a large extent are morphologically and behaviorally isogamous. No mucilage or mucilage structures are observed. Zygotes and auxospores have no contact with parental frustules, and their orientation is rather irregular though they tend to lie parallel to each other. Evaluation of the position of cardinal points in the life cycle of the species, and the rate of cell size decrease in culture are presented. In the breeding system of this species both homo- and heterothallic ways of reproduction are realized. The latter is basic and predominant. Among the 36 clones investigated, 16 were sexually compatible with the other 20. Homothallic behavior was extremely rare; only one clone displayed a homothallic mode of reproduction.
\end{abstract}

Key words: auxosporulation, Haslea karadagensis, heterothallism, sexual reproduction

\section{Introduction}

The diatom genus Haslea SimOnSEN is well known partly because of Haslea ostrearia (GAILlON) R. SiMONSEN, which produces the specific pigment "marennine" and is responsible for the greening of oysters. Several occurrences of $H$. ostrearia have been reported worldwide, without any serious doubts being raised about the identification of this species. Recently, a pennate diatom with colored apices resembling $H$. ostrearia was isolated from the Black Sea. Some morphological features of the two species turned out to be very similar, linking them to the same genus Haslea. However, examination of a full range of characteristics, including the morphology of the frustules and pigment features (optical characteristics in UV spectrophotometry and the Raman spectral signature) allowed us to differentiate $H$. ostrearia from this newly isolated diatom, which has been named $H$. karadagensis (GASTINEAU et al., submitted). Diatom classification, which was long based mainly on morphological features, has now adopted new methods, with molecular genetic analysis being the most modern (MeduIN 2003; ManN \& Evans 2007). Preliminary investigations indicated molecular differences between $H$. ostrearia and the closest relative, H. karadagensis. Unfortunately, the methods of molecular analysis, even though they are sensitive, objective, and applicable even at the subspecies level, are not indicative of a species difference per se (e.g. Orsini et al. 2002; Cerino et al. 2005). They do not prove that evolutionary divergence has been completed, considering emerging reproductive isolation. In some cases, it is virtually impossible 
to assess solely from the results of genetic analysis whether plainly-distinguishable groups of clones represent several morphotypes/genotypes of the same species or separate species (e.g. KACZMARSKA et al. 2009). In such cases, the concept of the biological species, which is based on the ability to interbreed, is a likely approach to be applied (MANN 2010), and is increasingly being used (AMATo et al. 2007; VANORMELINGEN et al. 2007, 2008; CASTELEYN et al. 2008; D'Alelio et al. 2009; KACZMARSKA et al. 2009; TROBAJo et al. 2009).

Sexual reproduction of $H$. ostrearia was first observed in monoclonal cultures (NeuviLle \& DASTE 1975, 1979), where it was homothallic, as these authors did not attempt to cross-breed their strains. The heterothallic mode of reproduction was not induced and reported until three decades later (DAVIDOvich et al. 2009), and a sexual process corresponding to type IB2a according to GEITLER's (1932, 1935) system was ascertained. In the present paper we describe and illustrate the sexual reproduction of $H$. karadagensis, the species from the genus Haslea isolated from the Black Sea, and demonstrate its sexual incompatibility with $H$. ostrearia. The cardinal points in the life cycles of the two species are compared, and their breeding systems analyzed.

\section{Materials and methods}

Over a period of three years (2008-2011) a total of 41 clones of $H$. karadagensis were derived from natural population that inhabits the pebble sublittoral near the Karadag biological station, Ukraine $\left(44^{\circ} 54^{\prime} 41^{\prime \prime} \mathrm{N}\right.$, $35^{\circ} 12^{\prime} 04^{\prime \prime}$ E). Samples were collected at a depth of $0.2-0.4 \mathrm{~m}$. Monoclonal cultures were started as single cells isolated by micropipettes, and were designated as Y.MMDD- $Z$, where $Y$ is the last number of the year of isolation, MM is the month, DD is the date, and $\mathrm{Z}$ is a short form of the name of the clone. Clonal and mixed cultures used for testing sexual compatibility were incubated in glass Petri dishes $(50-60 \mathrm{~mm}$ diameter) in artificial seawater, ESAW medium (ANDERSEN et al. 2005, p. 494). Mixtures of clones were produced using exponentially-growing cultures. Natural lighting from a north-facing window at $20 \pm 2^{\circ} \mathrm{C}$, or in low light under 'cool-white' fluorescent tubes (c. $20 \mu \mathrm{mol}$ photons. ${ }^{-}$ ${ }^{2} \cdot \mathrm{s}^{-1}$ ), and with a long-day artificial photoperiod, 14/10 $\mathrm{h}$ light/dark cycles, was used to ensure better vegetative growth, and the best sexual productivity was achieved at lower irradiances $\left(<50 \mu \mathrm{mol}\right.$ photons. $\left.\mathrm{m}^{-2} \cdot \mathrm{s}^{-1}\right)$ and with shorter photoperiods $(6-10 \mathrm{~h})$ (unpublished results). During a period of one week the mixed cultures were inspected daily for signs of auxosporulation under an
MBS-9 light microscope (LOMO, Leningrad, Russia), or a Nikon TS100 inverted microscope, using bright field (BF) optics. Sexual reproduction was deduced from the formation of gametes, zygotes, auxospores or initial cells. Photoimages were captured by Canon PowerShot A95 or Canon PowerShort A640 digital cameras through a Biolar PI microscope (PZO, Warsaw, Poland), equipped with a water immersion objective $\mathrm{x} 40$, numerical aperture 0.65 , operating in differential interference contrast (DIC) mode. The cell sizes were measured with a precision of 1.72 $\mu \mathrm{m}$ by using an ocular-ruler calibrated against an object-micrometer. Apart from the cells grown in the laboratory, the lengths of 1149 cells obtained from a natural population between 09 April and 08 May, 2008 were measured. Data for the cell sizes of $H$. ostrearia were obtained from the clones studied previously (DAvidovich et al. 2009), their sexual descendants, and some new clones obtained from samples collected in the oyster ponds of C. Pénisson ( $46^{\circ} 59^{\prime} 19^{\prime \prime} \mathrm{N} ; 2^{\circ}$ $\left.14^{\prime} 14^{\prime} \mathrm{W}\right)$. Mating incomparability of two species, $H$. karadagensis and $H$. ostrearia, was checked in mixtures of clones which were sexually competent and readily enter sexual reproduction if mixed inside the species. Before mating experiments, all the clones were acclimated during a week to the same salinity level of $30 \%$. The influence of salinity on vegetative growth rate and reproductive frequency was checked in the range of salinity from 8 to $40 \%$. Cultures maintained at $30 \%$ were acclimated to a chosen level of salinity (17, $23,30,40 \%$ ) during a week. Two-step acclimation was applied to reach lower levels, initially one week at 17 and then one week at 8 or 12\%. Every day during four days after reinoculation, the number of cells was counted in 20 fields of microscope view directly in Petri dishes, by using a water immersion objective. The growth rate (division per day) was calculated according to the exponential model. Reproduction frequency was calculated as a relative number of generative cells to the total number of generative and vegetative cells. We regarded cells as generative if they took part or arose in the process of sexual reproduction, i.e. gametangia, gametes, zygotes, auxospores, and initial cells. Two gametes were counted as a single generative cell. Mean values are presented as mean \pm standard error, referring $n$ to the number of measurements.

\section{Results}

\section{Life form and life cycle}

Haslea karadagensis was comparatively abundant in the samples collected in the vicinity of the Karadag Biology Station during the spring of years 2008, 2009, and 2010. The life form of the species is that of solitary highly motile cells, which are easily distinguishable in the samples 
Table 1. Summary of the cell length ranges in two Haslea species.

\begin{tabular}{lcccccc}
\hline & \multicolumn{3}{c}{ Haslea ostrearia } & \multicolumn{3}{c}{ Haslea karadagensis } \\
\hline & $\min$ & $\max$ & $n^{\text {a) }}$ & $\min$ & $\max$ & $n$ \\
Vegetative cells & 16 & 143 & 1484 & 22 & 97 & 1593 \\
Gametangia & 16 & 68 & 160 & 22 & 52 & 80 \\
Initial cells & 75 & 143 & 249 & 64 & 97 & 138 \\
\hline
\end{tabular}

a) $n=$ number of cells measured; min and max are minimal and maximal apical cell sizes occurred, $\mu \mathrm{m}$.

even under low magnification, because of their characteristic lancet shape and blue tips, with two big chloroplasts per cell, lying either side of the girdle and occupying around $2 / 3$ of the cell length (Fig. 1). A central cytoplasmic bridge across the vacuole contains the nucleus. The length of cells in the field population varied from 29 to $84 \mu \mathrm{m}$. Based on these data, and on measurements of cells used in our experiments, the full size range of the species Haslea karadagensis can be evaluated to span from 97 to $22 \mu \mathrm{m}$ (Table 1). Cells became sexually inducible after their size decreased below $52 \mu \mathrm{m}$, and they maintained an ability to reproduce sexually down to the smallest cell sizes observed $(22 \mu \mathrm{m})$. The sexually-inducible size range occupies $40 \%$ of the full size range. Initial cells resulting from sexual reproduction ranged in size from 64 to $97 \mu \mathrm{m}$, thus covering $44 \%$ of the total species-specific size range.

Cell sizes were measured at intervals of two to seventeen months in thirteen clones maintained in culture under natural light from north window, and at a temperature of $19-21^{\circ} \mathrm{C}$. This allowed us to calculate a mean cell size reduction rate, which was equal to $2.85 \pm 0.42 \mu \mathrm{m} /$ month $(n=13)$.

\section{Sexual reproduction}

Sexual reproduction in the species investigated in heterothallic pairs of clones began by the pairing of two cells (gametangia) originated from different clones. Heterothallism was easily inferred from the different cell sizes of the clones (Figs 2-4). The gametangia positioned themselves girdle-to-girdle by active gliding (Fig. 2). Pairing involved no visible (under BF or DIC optics) accumulation of mucilage, such as occurs in some other raphid diatoms. When the cells were paired, the chloroplasts changed position, moving from the girdle zone to the valves (compare Fig. 1 and Fig. 2), but did not divide. At the end of meiosis, each gametangium contained two spherical gametes, lying either side of the median transapical section (Fig. 3). As this occurred, the gametangial thecae were usually forced apart. Gamete development in one gametangium occurred more or less synchronously with that in the other gametangium, but not perfectly. It could be often seen that the gametes in one gametangium appeared to be slightly swollen (Fig. 4). Syngamy took place between the gametes closest to each other: first one pair of gametes fused and then, after an interval of a few minutes to tens of minutes, the next pair fused (Figs 5, 6). During meiosis, each gamete inherited one of the two chloroplasts of the parental cell, and as a result of plasmogamy, the zygote contained two plastids transmitted bi-parentally (Fig. 5). The zygotes tended to be formed between the gametangial thecae, and within a short time after syngamy each zygote contracted a little and, as a result, was approximately the same size as a single gamete (Fig. 7). There was no close contact between zygotes and gametangial thecae, and there was no visible mucilage capsule around them. The disposition of the gametes was therefore rather irregular relative to the gametangial frustules. Within an hour, the zygotes started to swell, and from this time they can be designated as auxospores (Fig. 8). Expansion was bipolar, and was not strictly oriented relative to gametangial thecae (Fig. 9); there was only slight tendency of auxospores to expand parallel to each other, and more or less parallel to the parental frustules (Figs 10-12). The growing auxospores contained a blue pigment that was clearly visible in the space free of chloroplasts (Fig. 9), and in the zygotes and gametes. Expanding (Fig. 9) and fully-developed (Fig. 10) auxospores retained the remnants of a zygote envelope as caps at the cell ends. Normally each gametangial pair produced two initial cells of similar size (Fig. 10), but sometimes the initial cells in a pair were noticeably different in size 


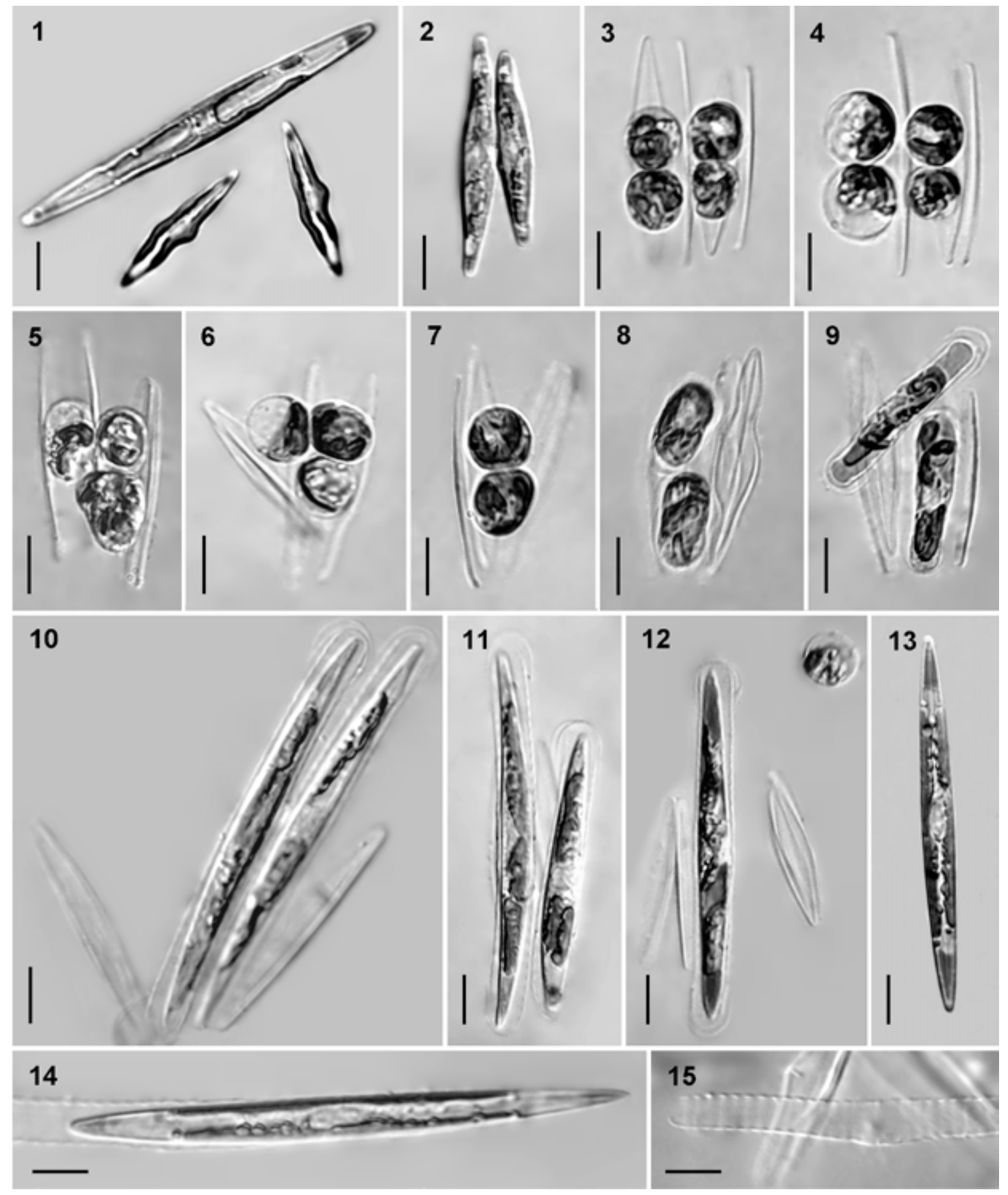

Figs 1-15. Haslea karadagensis vegetative and generative cells, light microscopy, differential interference contrast: (1) during the life cycle the cell apical length decreases up to four fold, cells growing in culture may get deformities; (2) pairing of gametangia is the first visible sign of the sexual reproduction process, note different size of cells belonging to two sexually compatible clones; (3) each gametangium in a pair produced two spherical gametes; (4) sometimes gametes of one gametangium are slightly swelled; (5) the moment of gametic syngamy (lower pair of gametes); (6) two gametes just before fusion (above) and a young zygote (below); (7) two resulted zygotes are surrounded with gametangial thecaes but have no tight contact with them; (8) zygotes started to grow, from this moment they may be termed auxospores; (9) zygote envelope remains are seeing as "caps" at the ends of growing auxospores, note cytoplasm at the ends of auxospores colored with marennine; (10) initial cells formed inside the fully developed auxospores; (11) the auxospore extension process is not fully synchronized, in a pair one auxospore may stop to grow earlier and form shorter initial cell; (12) just one zygote in a gametangial pair developed into initial cell, while another one aborted at the early stage; (13) tips of initial cells are typically colored with marennine; (14) escape of the initial cell from the perizonium envelope; (15) perizonium has visible transverse bands. Scale bar $10 \mu \mathrm{m}$. 


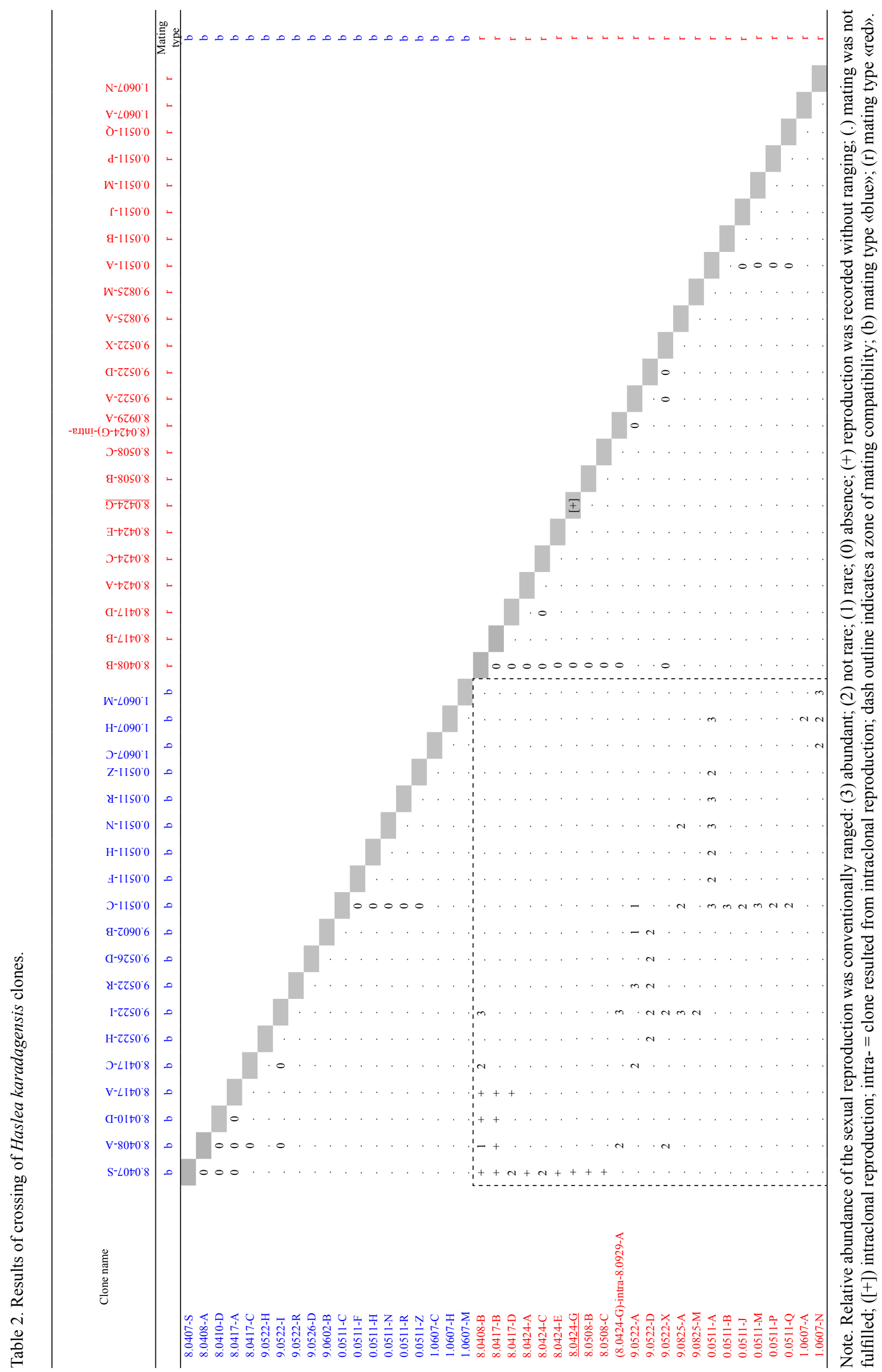


$\forall-\operatorname{tz\varsigma } 0600.0 . .$.

W-

Dttt0 80000.000

J-trt0.8 0000.000

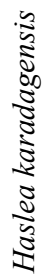

$\forall-t r t 080000.000$

g- $80+0.8 \circ 000 \cdot 000$

$\mathrm{H}^{-} \mathrm{II} \varsigma_{0} 0^{\circ} 0$

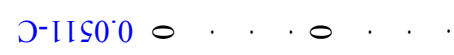

g-20906 60 ○ . . . . .

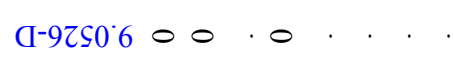

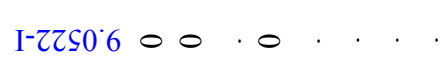

V-LIt0 80000.000

$\mathrm{S}-\angle 0 t 0.80000 .000$

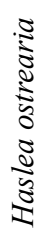
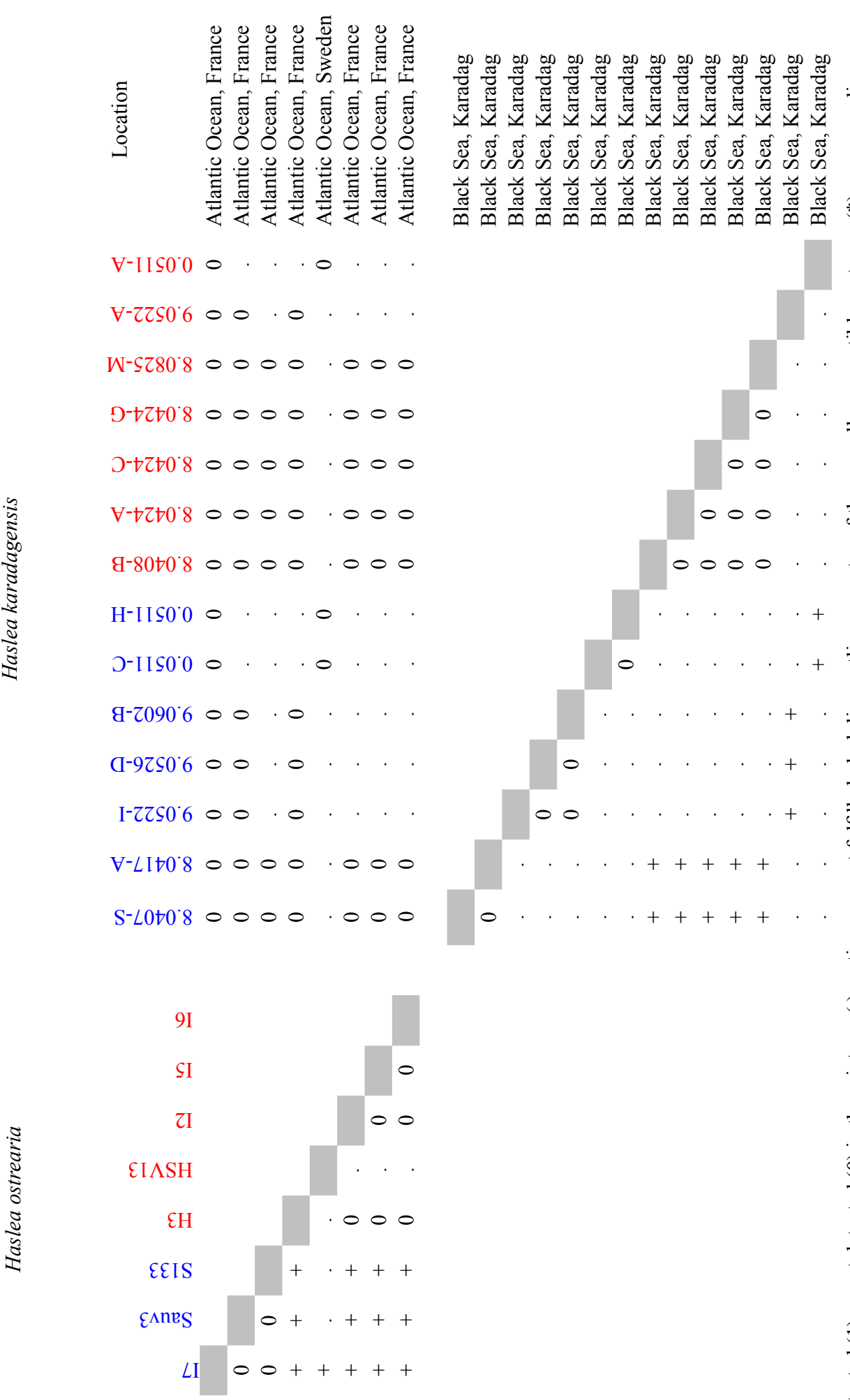

$$
\text { 年 }
$$$$
\text { . }
$$

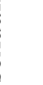

$$
\text { 言 }
$$


(Fig. 11). In some cases only one initial cell of a pair survived (Fig. 12). The perizonium was well developed, with conspicuous transverse bands (Figs $10-12,14-15), 4.2 \pm 0.1$ in $10 \mu \mathrm{m}(n=26$, range $3.3-5.1$ ). All transverse perizonial bands, with the exception of the central or primary band, had approximately the same diameter. The auxospore stopped expanding when 13-17 transverse bands had been produced on either side of the primary band. Because of the lancet shape of the initial cell laid down inside the perizonium with parallel walls, there was a noticeable gap between the wall of perizonium and thecae of the initial cells, which broadened toward the end of the cell (Figs 10-12). Some of the initial cells were slightly bent (Figs 10,11); others were not (Figs 12,13). The initial cells escaped from the perizonium by active gliding (Fig. 14). The tips of the initial cell were normally colored by blue pigment (Fig. 13).

\section{Breeding system}

Sexual reproduction was achieved mainly in the mixtures of clones which were sexually compatible (Table 2), thus demonstrating that heterothallic reproduction did occur. We could not observe intraclonal reproduction directly, and so we cannot describe the pattern of homothallic sexual reproduction, although there was indirect evidence that it happened once in clone 8.0424$\mathrm{G}$, where initial cells resulting from sexual reproduction were found. Isolated homothallic descendant $(8.0424-\mathrm{G})-$ intra-8.0929-A was of the same sex as the parent clone, and was shown to be sexually compatible with clones of the opposite sex. Several auxospores were found in the mixture of clones of the same sex, 8.0408-B and 8.0424-C, which we attributed to homothallic reproduction of one or both clones. No other occurrences of homothallic reproduction were recorded. If clones were sexually compatible and had suitable cell sizes, gametes and young zygotes were usually seen 3-5 days after exponentially growing clonal cultures had been mixed. If two sexually-compatible clones had differing cell sizes, the members of each of the gametangial pairs in the mixture of these clones were unequal in length, which suggested a heterothallic mode of reproduction.

Numerous attempts to mate Haslea ostrearia from the Atlantic Ocean with $H$. karadagensis from the Black Sea were unsuccessful (Table 3). We used different clones, including control pairs of each species that reproduced vigorously when mated separately. Over two years more than 20 interbreeding experiments were carried out with the clones of both species grown at the same culture conditions, favorable for reproduction, i.e. salinity $30 \%$, low irradiance, and short photoperiod (Mouget et al. 2009). In every experiment, sexual reproduction was observed in the pairs of clones consisting of the same species, but not in mixed pairs. We did not check the breeding compatibility of the species producing a blue pigment with strictly different colorless members of the genus Haslea.

\section{Relation to salinity}

H. karadagensis was capable to grow at different salinities in the range from 8 to at least 40\% (Fig 17). Cells were alive at $8 \%$ but their growth rate was close to zero. Shift of salinity from lower to higher levels was more favorable for vegetative growth if compared with the opposite change from higher to lower levels. Salinity of $25-30 \%$ was optimal for vegetative growth. Unlike vegetative growth, sexual reproduction was impossible at salinity less than $17 \%$ (Fig. 18). Higher levels of salinity were favorable for sexual reproduction. Moreover, the more shift of the salinity level was applied in the range from 17 to $40 \%$, the more frequency of reproduction observed in clones acclimated to 17,23 , and $30 \%$. The highest reproduction frequency was achieved if clones acclimated to $17 \%$ were transferred (reinoculated) into $40 \%$ medium.

\section{Discussion}

Mating experiments allowed us to demonstrate reproductive isolation between Atlantic $H$. ostrearia and $H$. karadagensis from the Black Sea. These two species are essentially different from other members of the genus; because of the specific blue pigments they produce. Their explicit inability to interbreed is evidence in favor of the Biological Species Concept, and confirms the existence of "biological species" in diatoms in particular (see MANN 1999, 2010). Morphological, physiological, biochemical, and genetic differences are useful, and can very often be used to differentiate between species, but they are not sufficient if we are trying to find out whether a particular population has divided during the course of its evolutionary history or not. In this respect 


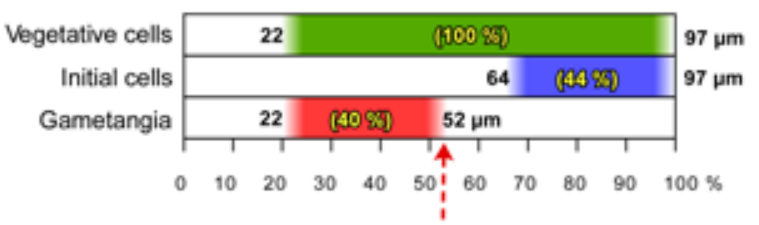

Fig. 16. Diagram showing the spans of the life cycle stages in Haslea karadagensis. The percentage of the full size occupied by a particular stage is shown in brackets. The upper size limit critical for sexualization is indicated by a dotted arrow.

inherited in generations, or from the fact that one gametangium had accidentally released its gametes before the other. An unfavorable disposition of the gametangial frustules might further impede immediate copulation, thus leading to swelling of the gametes released first. Gamete behavior of this type could formally be classified as anisogamous (cis-anisogamy), which corresponds to category IA2 in Geitler's classification (GeITLER 1973; Round et al. 1990; MANN 1993). However, from the data obtained we cannot conclude that this differentiation in behavior corresponds to the two sexes. In many other cases, the gametes appear to be both morphologically and behaviorally similar, and the pattern of sexual reproduction in these cases can be assigned to the Geitler's type IB2a. Isogamous behavior has also been shown to be typical of H. ostrearia (DAVIDOVICH et al. 2009).

$H$. karadagensis has a well-developed perizonium like $H$. ostrearia (DAVIDOVICH et al. 2009). In both species the initial valves do not exactly match the internal shape of the perizonium. The lancet form of the initial cells differs significantly from the tube shape of the perizonium. This implies that the perizonium does not simply act as a "mold" for the initial cell, and the regulation of the process of shaping the initial cell is obviously more complex. Slight curvature is also a characteristic of initial cells (Figs 10, 11, 14), which is not unusual (Cox 2010), as are the not-unusual cell deformities (Fig. 1) acquired by cultured specimens during their life history (KocioleK \& STOERMER 2010).

The mating system of these species combines two modes: homothallic and heterothallic. However, while heterothallism was an almost constant feature of the 37 clones studied when they were mated in various pair-wise combinations, homothallic reproduction was detected in only one monoclonal culture. Furthermore, heterothallic reproduction was much more productive, resulting in tens to hundreds of gametangial pairs per Petri we should acknowledge that, despite certain similarities between their morphological features, such as pigment characteristics etc., Atlantic $H$. ostrearia and Black Sea H. karadagensis are distinct biological species, and they are both different from other Haslea species.

Twofold difference in the level of salinity of water in Atlantic Ocean and the Black Sea cannot be regarded as a factor that prevents interbreeding. Literature data (Wraige et al. 1998; DAVIDOvich et al. 2009) and our experiments show that these two species are osmotolerant organisms which have relatively broad and overlapping salinity tolerance ranges; they grew and reproduced sexually most copiously at $25-30 \%$. Moreover, increase of salinity was favorable for sexual reproduction of $H$. karadagensis and correlation between the increment of salinity and frequency of sexual reproduction was positive (Fig. 18).

The life cycle of $H$. karadagensis can be regarded as typical of many other pennate diatoms. Cells become sexually inducible after their apical length has reached a cardinal point (sensu GeITLER 1932) of around $52 \mu \mathrm{m}$. This critical threshold corresponds to $54 \%$ of the maximum speciesspecific size in this species (Fig. 16), and fits in with the general tendency in diatoms (DAVIDOVICH 2001). The sexually-inducible size is openended. This means that even the smallest cells at the end of their life span can still engage in sexual reproduction. Smaller gametangia usually give rise to smaller initial cells, while bigger gametangia produce bigger initial cells (DAVIDOVICH 2001). In our case, the size restitution factor found for the smallest gametangia was equal to $64 / 22=2.9$, whereas that for the biggest ones was $97 / 52=1.9$. Taking into account a cell size reduction rate of $2.85 \mu$. month $^{-1}$, the total duration of the life cycle can be calculated to be $(97-22) / 2.85=26$ months or 2.2 years for the biggest initial cells, and markedly shorter for the smallest ones, (64$22) / 2.85=15$ months or 1.2 year. The biggest initial cells take about $(97-52) / 2.85=16$ months to reach the sexually-inducible size range, whereas the smallest initial cells take only $(64-52) / 2.85=4$ months. These are a very rough estimation, and correspond to the growth conditions used here. Moreover, we know nothing about the change in the cell size reduction rate during the life cycle, something that has been observed, for example, in Pseudo-nitzschia species (Амато et al. 2005; D'Alebio et al. 2009). A life cycle lasting more than one year $(2-40$ y) is thought to be common 

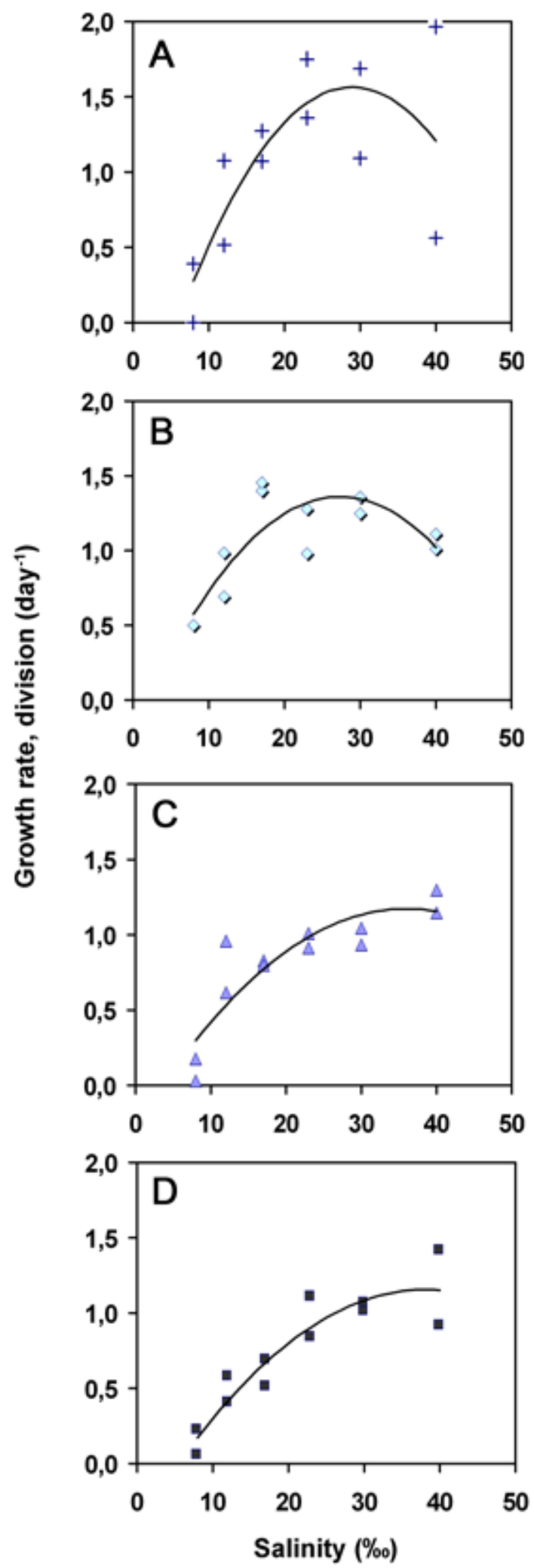

Fig. 17.Dependence of the growth rate of Haslea karadagensis on the salinity level. Before experiment cultures were acclimated during a week to salinities 12 (A), 17 (B), 23 (C), and $40 \%$ (D). Data are smoothed by quadratic polynomial.

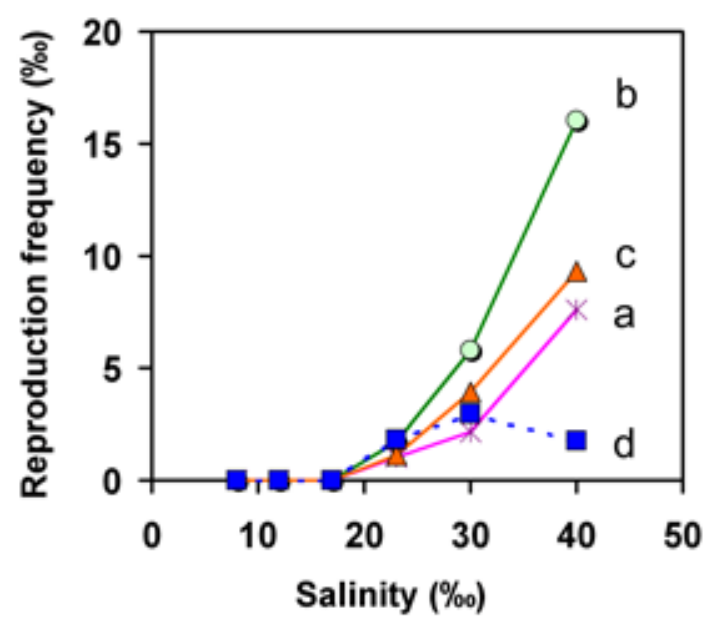

Fig. 18. The effect of salinity on the frequency of sexual reproduction. Each point corresponds to a mean value obtained as a result of mating of two pairs of sexually compatible clones $0.0511-\mathrm{A}+0.0511-\mathrm{N}$ and $0.0511-\mathrm{C}+$ 0.0511-M. Before mating clones were acclimated during a week to salinities 12 (a), 17 (b), 23 (c), and $40 \%$ (d).

among diatoms (Lewis 1984; MANN 1988; Jewson 1992; D'Alelio et al. 2010). Our calculations suggest that sexual events may occur annually in culture; however we cannot say anything about the natural population of $H$. karadagensis, given that there is no information on how fast cells divide in natural conditions.

In H. karadagensis, the gametangial apical size region occupies $40 \%$ of the total size range in this species, which is very similar to the situation in $H$. ostrearia $(41 \%)$. The initial cell size region amounts to 44 and $54 \%$ of the total size in $H$. karadagensis and $H$. ostrearia, respectively. In some diatoms the smallest initial cells resulting from sexual reproduction are small enough to be sexualized, and thus able to embark on a new round of auxosporulation immediately (Roschin 1994; CHEPURNov et al. 2004). Multistep auxosporulation and size restitution have not previously been recorded in $H$. karadagensis or $H$. ostrearia, and theoretically, in view of the absence of overlap of the size regions of initial and gametangial cells, it seems unlikely to occur.

There is some uncertainty about the pattern of sexual reproduction in the species investigated. In some gametangial pair we could see that both gametes in one gametangium were slightly swollen (Fig. 4). This may promote syngamy, but might be also a single way to achieve contact between gametes, as no one form of gamete motion was observed. Slight asynchrony could have resulted either from anisogamy related to the sexes and 
dish (bottom area c. $20 \mathrm{~cm}^{2}$ ), in contrast to just a few occurrences of auxosporulation in the case of intraclonal reproduction. Unfortunately, the environmental cues that trigger homothallic reproduction in some $H$. karadagensis strains are still unknown, as it is in H. ostrearia strains.

Depending on their mating compatibility, the clones could be divided into two groups, mating types of which we designated conventionally as "red" and "blue". The mating type capable of intraclonal reproduction was classified as "red". A total of 19 clones from a natural population were found to be type "blue", and 22 were "red". The ratio of sexes in the population could be regarded thus as more or less equal.

In conclusion, it should be emphasized that species description and taxonomy that in diatoms have so far been based predominantly on morphological features (Cox 2009, 2010; MANN 2010) need to be accompanied by another approaches. The reproductive biology methods can provide most decisive characteristics (MANN 2010). To reach a comprehensive description of a species, its reproductive biology characteristics must be regarded not as a "good-looking" supplementation but as an integral part of the species diagnosis. Life cycle, sexual behavior, and breading system are the most important characteristics of the species biology. From this standpoint, the results reported here represent the "end point" in the description of H. karadagensis. Furthermore, the data obtained are also important for analyzing the discrepancies/similarities between representatives of the genus Haslea. So far, the reproductive biology of two species of the genus, namely $H$. ostrearia and $H$. karadagensis, has been described. The investigation of sexual reproduction patterns of colorless, sternumbearing members of the genus appears to be prospective.

\section{Acknowledgments}

We gratefully acknowledge receiving financial help from EGIDE (France) and Ministry of Education and Science of Ukraine to provide funds for travel and other expenses (PHC DNIPRO), and we thank Université du Maine for providing facilities for two of us (N.A.D., O.I.D.).

\section{References}

Amato, A.; Kooistra, W.H.C.F.; Levialdi Ghiron, J.H.; Mann, D.G.; Pröschold, T. \& Montresor, M. (2007):
Reproductive isolation among sympatric cryptic species in marine diatoms. - Protist 158: 193-207.

Amato, A.; Orsini, L.; D’Alelio, D. \& Montresor, M. (2005): Life cycle, size reduction patterns, and ultrastructure of the pennate planktonic diatom Pseudo-nitzschia delicatissima (Bacillariophyceae). - Journal of Phycology 41: 542-556.

Andersen, R.A.; Berges, J.A.; Harrison, P.J. \& Watanabe, M.M. (2005): Recipes for freshwater and seawater media. - In: Andersen, R.A. (ed.): Algal culturing techniques. - pp. 429-538, Elsevier Academic Press, London.

Casteleyn, G.; Chepurnov, V.A.; Leliaert, F.; Mann, D.G.; Bates, S.S.; Lundholm, N.; Rhodes, L.; Sabbe, K. \& Vyverman, W. (2008): Pseudo-nitzschia pungens (Bacillariophyceae): A cosmopolitan diatom species? - Harmful Algae 7: 241-257.

Cerino, F.; Orsini, L.; Sarno, D.; Dell'Aversano, C.; TARTAGLIONE, L. \& ZingONE, Z. (2005): The alternation of different morphotypes in the seasonal cycle of the toxic diatom Pseudo-nitzschia galaxiae. - Harmful Algae 4: 33-48.

Chepurnov, V.A.; Mann, D.G.; Sabbe, K. \& Vyverman, W. (2004): Experimental studies on sexual reproduction in diatoms. - International Review of Cytology 237: 91-154.

Cox, E.J. (2009): What's in a name? - Diatom classification should reflect systematic relationships. - Acta botanica croatica 68: 443-454.

Cox, E.J. (2010): Morphogenetic information and the selection of taxonomic characters for raphid diatom systematics. - Plant Ecology and Evolution 143: 271-277.

D’Alelio, D.; Amato, A.; Kooistra, W.H.C.F.; Procaccini, G.; CAsotti, R. \& Montresor, M. (2009): Internal transcribed spacer polymorphism in Pseudonitzschia multistriata (Bacillariophyceae) in the Gulf of Naples: recent divergence or intraspecific hybridization? - Protist 160: 9-20.

D’Alelio, D.; Amato, A.; Luedeking, A. \& Montresor, M. (2009): Sexual and vegetative phases in the planktonic diatom Pseudo-nitzschia multistriata. Harmful Algae 8: 225-232.

D'Alelio, D.; D'Alcalà, M.R.; Dubroca, L.; Sarno, D.; Zingone, A. \& Montresor, M. (2010): The time for sex: A biennial life cycle in a marine planktonic diatom. - Limnology and Oceanography 55: 106114.

Davidovich, N.A. (2001): Species specific sizes and size range of sexual reproduction in diatoms. - In: Economou - Amilli, A. (ed.): Proceedings of the 16th International Diatom Symposium. - pp. 191196, University of Athens, Athens.

Davidovich, N.A.; Mouget, J.-L. \& Gaudin, P. (2009): Heterothallism in the pennate diatom Haslea ostrearia (Bacillariophyta). - European Journal of Phycology 44: 251-261.

GEITLER, L. (1932): Der Formwechsel der pennaten Diatomeen (Kieselalgen). - Archiv für Protistenkunde 78: $1-226$.

GeitLer, L. (1935): Reproduction and life history in diatoms. - Botanical Review 1: 149-161.

Geitler, L. (1973): Auxosporenbildung und Systematik bei pennaten Diatomeen und die Cytologie von Cocconeis-Sippen. - Österreichische Botanische 
Zeitschrift 122: 299-321.

Jewson, D.H. (1992): Size reduction, reproductive strategy and the life cycle of a centric diatom. - Philosophical Transactions of the Royal Society of London B 335: 191-213.

Kaczmarska, I.; Ehrman, J.M.; Moniz, M.B.J. \& Davidovich, N. (2009): Phenotypic and genetic structure of interbreeding populations of the diatom Tabularia fasciculata (Bacillariophyta). - Phycologia 48: 391403.

Kociolek, J.P. \& Stoermer, E.F. (2010): Variation and polymorphism in diatoms: the triple helix of development, genetics and environment. A review of the literature. - Life and Environment 60: 75-87.

Lewis, W.M., Jr. (1984): The diatom sex clock and its evolutionary significance. - The American Naturalist 123: 73-80.

Mann, D.G. (1988): Why didn't Lund see sex in Asterionella? A discussion of the diatom life cycle in nature. - In: Round, F.E. (ed.): Algae and the Aquatic Environment. - pp. 384-412, Biopress Ltd., Bristol. U.K.

Mann, D.G. (1993): Patterns of sexual reproduction in diatoms. - Hydrobiologia 269/270: 11-20.

Mann, D.G. (1999): The species concept in diatoms (Phycological Reviews 18). - Phycologia 38: 437 495.

ManN, D.G. (2010): Discovering diatom species: is a long history of disagreements about species-level taxonomy now at an end? - Plant Ecology and Evolution 143: 251-264.

Mann, D.G. \& Evans, K.M. (2007): Molecular genetics and the neglected art of diatomics. - In: BRodiE, J. \& LEwIS, J.M. (eds): Unraveling the algae - the past, present and future of algal molecular systematics. pp. 231-265, CRC Press, Boca Raton, Florida.

MedLIN, L.K. (2003): Application of molecular techniques for genetic differentiation of microalgae. - In: NORTON, T. A. (ed.): Out of the Past. Collected Reviews to Celebrate the Jubilee of the British Phycological Society. - pp. 31-48, Dataplus Print \& Design (Dunmurry), Belfast.

Mouget, J.-L.; Gastineau, R.; Davidovich, O.; Gaudin, P. \& Davidovich, N. (2009): Light is a key factor in triggering sexual reproduction in the pennate diatom Haslea ostrearia. - FEMS Microbiology Ecology 69: 194-201.

Neuville, D. \& Daste, P. (1975): Observations préliminaires concernant l'auxosporulation chez la diatomée Navicula ostrearia (Gaillon) Bory en culture in vitro. - Comptes Rendus de l'Académie des Sciences de Paris Série D 281: 1753-1756.

Neuville, D. \& Daste, P. (1979): Observations concernant les phases de l'auxosporulation chez la diatomée Navicula ostrearia (Gaillon) Bory en culture in vitro. - Comptes Rendus de l'Académie des Sciences de Paris Série D 288: 1496-1498.

Orsini, L., Sarno, D.; Procaccini, G.; Poletti, R.; Dahlmann, J. \& Montresor, M. (2002): Toxic Pseudo-nitzschia multistriata (Bacillariophyceae) from the Gulf of Naples: morphology, toxin analysis and phylogenetic relationships with other Pseudo-nitzschia species. European Journal of Phycology 37: 247-257.

Roshchin, A.M. (1994): Zhiznennye Tsikly Diatomovikh Vodoroslej. - 170 pp., Naukova dumka, Kiev. (in
Russ.)

Rossignol, N.; Jaouen, P.; Robert, J.-M. \& Quéméneur, F. (2000): Production of exocellular pigment by the marine diatom Haslea ostrearia Simonsen in a photobioreactor equipped with immersed ultrafiltration membranes. - Bioresource Technology 73: $197-200$.

Round, F.E.; Crawford, R.M. \& Mann, D.G. (1990): The Diatoms. Biology and Morphology of the Genera. 747 pp., Cambridge University Press, Cambridge.

Trobajo, R.; Clavero, E.; Chepurnov, V.A.; Sabbe, K.; Mann, D.G.; IsHIHARA, S. \& Cox, E.J. (2009): Morphological, genetic and mating diversity within the widespread bioindicator Nitzschia palea (Bacillariophyceae). Phycologia 48: 443-459.

Vanormelingen, P.; Chepurnov, V.A.; Mann, D.G.; Cousin, S.; Sabbe, K. \& Vyverman, W. (2007): Congruence of morphological, reproductive and ITS rDNA sequence data in some Australasian Eunotia bilunaris (Bacillariophyta). - European Journal of Phycology 42: 61-79.

Vanormelingen, P.; Chepurnov, V.A.; Mann, D.G.; Sabbe, K. \& Vyverman, W. (2008): Genetic divergence and reproductive barriers among morphologically heterogeneous sympatric clones of Eunotia bilunaris sensu lato (Bacillariophyta). - Protist 159: 73-90.

Wraige, E.J.; Belt, S.T.; Massé, G.; Robert, J.-M.; Rowlan, S.J. (1998): Variations in distributions of C25 highly branched isoprenoid (HBI) alkenes in the diatom, Haslea ostrearia: influence of salinity. - Organic Geochemistry. 28: 855-859.

(C) Czech Phycological Society (2012)

Received August 10, 2011

Accepted January 23, 2012 